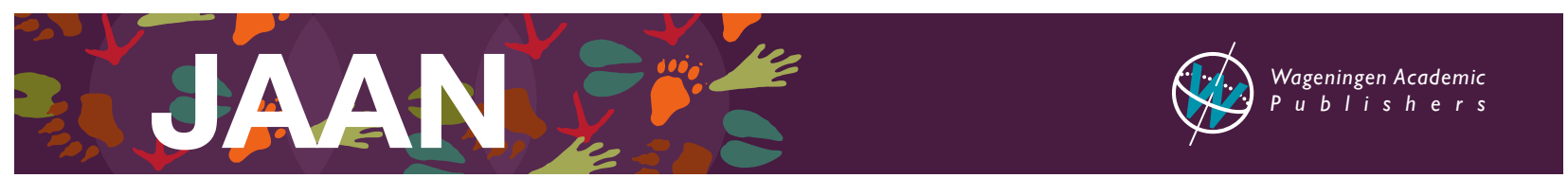

Journal of Applied Animal Nutrition, 2020; 8(3): 103-104

OPEN ACCESS

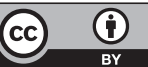

\title{
Response to letter from Tim Bailey
}

\section{J.M. Wilkinson and R.H. Young}

LETTER

Mr Bailey stresses that the use of soya in livestock feed is a major factor behind the growth of soya cultivation and associated deforestation in South America. We agree with him. This was our principal motivation in reviewing the evidence for alternative protein sources that can be used to replace soya bean meal and palm kernel meal in diets for livestock (Wilkinson and Young, 2020). There is significant use of soya bean meal in dairy farming, but the vast majority of use is in poultry and pork production (Food Climate Research Network ${ }^{1}$; Fraanje, 2020).

With the need to reduce soya use in mind, we also pointed out that the available evidence suggests that substantially less soya is used in the production of each litre of dairy cow milk than in the production of a litre of milk-like drink made directly from soya. This is particularly the case in the UK, we suggest, due to the relatively high use of grass and other forage crops in dairy cow nutrition. As such we are concerned that over time the trend towards increased consumption of soya drink/milk (Global Market Insights, 2017) will increase rather than decrease the demand for, and production of soya beans.

We accept his dry matter (DM) intake calculation for a housed dairy cow. However, some herds in the UK use no soya while others do not use soya at certain times of the year. More significantly, most of the DM in UK dairy cow diets is not associated with soya or deforestation, as a high proportion is grass and other human-inedible ingredients (Wilkinson, 2011).

In our review we used the best data we could obtain at the time to estimate how much soya bean meal is fed to dairy cows in the UK. Fraanje (2020) notes the incomplete and conflicting data on soya meal use in dairy cow feed in the UK, but estimates the use to be 300,000 tonnes, higher than our top figure of 173,000 tonnes. This may be an over-estimate since it is based on an average level of soya bean meal use in the Netherlands which may be higher than that in the UK. If we use Fraanje's estimate of 300,000 tonnes, this reduces the amount of milk produced per kilo of soya bean meal fed to dairy cows from 85 to 49 litres. This is nevertheless a 7-fold more efficient use of soya than making soya drink.

While it takes whole soya beans to make soya drink, livestock in the UK are fed on soya bean meal, the byproduct from soya oil extracted for human use. As our review makes clear, there is considerable potential to reduce the use of soya bean meal in dairy cow diets without affecting productivity. There would appear to be no similar potential to reduce soya bean use in the production of soya drink.

At the time of publication, we were unaware that soya drink sold in the UK is made from soya grown in Europe. We accept this frees UK soya drink from direct association with deforestation. Nevertheless, Europe is a major importer of soya beans. For example, France, a significant producer of soya in Europe, imported over 600,000 tonnes of soya in 2019, of which $62 \%$ was from USA and Brazil. ${ }^{2}$

With demand for soya drink increasing, additional use increases global demand for soya beans which, directly or indirectly, results in land use change including deforestation. In the Great Plains region of the USA, for example, 53 million acres of species-rich grassland were ploughed between 2009 and 2016 (World Wildlife Fund, 2016), 16\% of which went into soya bean production (World Wildlife Fund, 2017). While this may not be as serious as rainforest destruction, the reduction in natural grassland has resulted

\footnotetext{
${ }^{1}$ https://www.foodsource.org.uk/building-blocks/soy-food-feed-and-land-use-change.

${ }^{2}$ https://trendeconomy.com/data/h2/France/1201.
} 
in substantial biodiversity and habitat loss (World Wildlife Fund, 2017) with associated increased greenhouse gas emissions as soil organic matter is degraded (Garnett et al., 2017; Johnston et al., 2009).

There was no funding for the production of our review. Richard Young is an employee of the Sustainable Food Trust and an organic beef and sheep farmer. All his animals are fed only on grass and conserved grass. In 51 years as a farmer he has never used any soya. Professor Wilkinson is an honorary Special Professor in the School of Biosciences at the University of Nottingham and a consultant to the livestock industry.

\section{References}

Fraanje, W., 2020. Soy in the UK: what are its uses? Food Climate Research Network, UK. Available at: https://www.fcrn.org.uk/ fcrn-blogs/soy-uk-what-are-its-uses.

Garnett, T., Godde, C., Muller, A., Röös, E., Smith, P., de Boer, I., zu Ermgassen, E., Herrero, M., Van Middelaar, C, Schader, C. and Van Zanten, H., 2017. Grazed and confused? Food Climate Research Network, UK. Available at: https://www.fcrn.org.uk/sites/default/ files/project-files/fcrn_gnc_report.pdf.

Johnston, A.E., Poulton, P.R. and Coleman, K., 2009. Soil organic matter: its importance in sustainable agriculture and carbon dioxide fluxes. Advances in Agronomy 101: 1-57.

Wilkinson, J.M., 2011. Redefining efficiency of feed use by livestock. Animal 5: 1014-1022.

Wilkinson, J.M. and Young, R.H., 2020. Strategies to reduce reliance on soya bean meal and palm kernel meal in livestock nutrition. Journal of Applied Animal Nutrition 8: 75-82. https://doi.org/10.3920/ JAAN2020.0007

World Wildlife Fund, 2016. Plowprint annual report 2016: facts and figures. World Wildlife Fund, Bozeman, MT, USA, 8 pp. Available at: https://tinyurl.com/yxutkutu.

World Wildlife Fund, 2017. Plowprint report 2017. World Wildlife Fund, Bozeman, MT, USA, 12 pp. Available at: https://tinyurl. com/t3ktvjb. 